\title{
ZARZĄDZANIE BIUREM NIERUCHOMOŚCI NA PRZYKŁADZIE CZĘSTOCHOWSKIEJ KANCELARII NIERUCHOMOŚCI
}

\author{
Eukasz Kubacki \\ Politechnika Częstochowska \\ Wydział Zarządzania
}

\begin{abstract}
Streszczenie: Głównym celem artykułu jest ukazanie specyfiki zarządzania biurem nieruchomości. Opracowanie zostało podzielone na część teoretyczną i empiryczną. W wywodzie teoretycznym scharakteryzowano zawód pośrednika nieruchomości w zarządzaniu biurem nieruchomości, jego obowiązki oraz kluczowe cele działania. Artykuł został wzbogacony o charakterystykę jednego z częstochowskich biur nieruchomości. Część empiryczną stanowi badanie ankietowe przeprowadzone na klientach wspomnianego biura. Zgromadzone dane pozwoliły ocenić wagę zawodu pośrednika nieruchomości oraz intensywność korzystania z jego usług podczas zarządzania biurem nieruchomości.
\end{abstract}

Słowa kluczowe: nieruchomość, pośrednik nieruchomości, zarządzanie biurem nieruchomości, właściciel nieruchomości

DOI: $10.17512 /$ znpcz.2018.1.10

\section{Wprowadzenie}

W dzisiejszych czasach ludzie bardzo często korzystają z pomocy osoby wykwalifikowanej, która posiada doświadczenie w sprzedaży lub nabyciu nieruchomości, aby nie narazić się na dodatkowe niepotrzebne koszty, jak również na odpowiedzialność przed sądem. Pośrednik w obrocie nieruchomościami jest od samego początku z klientem - od podpisania umowy po odbiór kluczy do wymarzonej nieruchomości. Każdy dokładny doradca analizuje realna cenę, za jaką można sprzedać bądź kupić daną nieruchomość (Bryx 2008, s. 24). Rzetelnie zbiera informacje dotyczące nieruchomości, przegląda dokładnie treść księgi wieczystej, jeśli taka istnieje, sprawdza wnikliwie stan prawny oraz czy nieruchomość nie jest w jakiś sposób zadłużona (Tomski, Sitek (red.) 2011, s. 10). Podczas wizyty na danej nieruchomości zostają wykonane jej zdjęcia, które w późniejszym czasie, po dokładnym przeanalizowaniu rynku dla danego rodzaju nieruchomości, będą umieszczone na wszystkich wiodących portalach nieruchomości w Polsce. Miarą szybkiej sprzedaży lub kupna nieruchomości jest skuteczny marketing i duże doświadczenie pośrednika oraz zbudowana przez niego przez lata pracy baza klientów (Cabała (red.) 2018, s. 36). Każde biuro nieruchomości pomaga klientowi również w zakresie znalezienia dobrego notariusza, który pomoże rzetelnie w realizacji kupna bądź sprzedaży nieruchomości. Zdobyta wiedza, duże doświadczenie 
i profesjonalne podejście do klienta stanowią podstawę do dużych sukcesów, o czym świadczy później liczne grono zadowolonych klientów.

\section{Zarządzanie biurem nieruchomości}

Procesem zarządzania biurem nieruchomości zajmuje się pośrednik nieruchomości. To on jest koordynatorem, który pozostaje odpowiedzialny za prawidłowe planowanie, organizowanie oraz kontrolę aspektów organizacyjnych biura nieruchomości. Ponadto odpowiada za przygotowanie, przekazanie, przewodzenie oraz archiwizację danych (Brzeski (red.) 2003, s. 11). Zadaniem pośrednika jest również kontrola postępów pracy oraz ocena jej wyników. Każde biuro nieruchomości powinno posiadać własną politykę obsługi klienta. Skuteczne zarządzanie relacjami z klientem jest istotnym czynnikiem osiągnięcia sukcesu biura nieruchomości (Wolniakowska 2013, s. 17). Nieodpowiednia obsługa ma bowiem negatywny wpływ na firmę.

Pracujący dla biura nieruchomości pośrednik jest odpowiedzialny za nawiązanie pierwszego kontaktu z potencjalnym klientem. Istotne jest, aby każde biuro nieruchomości w rzetelny sposób określiło swoją politykę obsługi klienta, a przede wszystkim potrafiło skutecznie ją wdrożyć. Pośrednicy biura nieruchomości nawiązują kontakt osobisty albo poprzez e-mail lub telefon. Istotnym elementem obsługi klienta jest rozwiązywanie konfliktów pomiędzy biurem nieruchomości a klientem. W momencie pojawienia się sytuacji konfliktowej należy wykazać dbałość o więzi oraz unikać sytuacji, gdzie wizerunek biura nieruchomości mógłby zostać zagrożony.

W każdym biurze stosuje się indywidualny system, który pozwala dokładnie pomóc klientom w sprzedaży ich praw do nieruchomości poprzez:

- kalendarz spotkań i określonych działań,

- automatyczne przypominanie o zaplanowanych zdarzeniach,

- możliwość kontroli procesów kontaktów telefonicznych poprzez notowanie działań,

- przechowywanie dokumentów elektronicznych w należytym formacie,

- historię realizowanych projektów oraz raportów z podglądów nieruchomości.

\section{Zawód pośrednika nieruchomości}

Dynamika rynku nieruchomości w Polsce spowodowała rozwój profesjonalnych zawodów specjalistów od spraw nieruchomości, takich jak (Bończak-Kucharczyk 2013, s. 296):

- rzeczoznawca majątkowy,

- pośrednik w obrocie nieruchomościami,

- zarządca nieruchomości.

Pośrednik nieruchomości to zawód oparty na tworzeniu relacji pomiędzy kupującym a sprzedającym nieruchomości. Przedmiotem transakcji jest zakup, sprzedaż, zamiana, najem lub wynajem nieruchomości (Brzeziński 2008, s. 119). 
W myśl ustawy o gospodarce nieruchomościami pośrednik w obrocie nieruchomościami to osoba fizyczna, która nabyła licencję zawodową (Obwieszczenie Marszałka Sejmu Rzeczypospolitej Polskiej z dnia 14 grudnia 2017 r. ..., art. 179 ust. 2).

Warto nadmienić, iż rok w 2013 okazał się przełomowym dla zawodu pośrednika nieruchomości. Otóż według obowiązującej deregulacji wykonywanie pośrednictwa $\mathrm{w}$ obrocie nieruchomościami nie wymaga już licencji. Potrzebne jest jedynie ubezpieczenie od odpowiedzialności cywilnej. W przypadku powstania szkód związanych $\mathrm{z}$ tą działalnością osoba, na rzecz której prowadzone jest zarządzanie nieruchomością, może dochodzić swych roszczeń także poprzez to ubezpieczenie (Ustawa z dnia 13 czerwca 2013 r. ..., art. 36).

W związku z tym działalność pośrednika nieruchomości oparta jest na usługach wobec osób trzecich. Pośrednik często odpowiada za olbrzymi majątek. Mowa tu o nieruchomościach lub płynących z nich dochodach. Ponadto wszelkie działania inwestycyjne w odniesieniu do nieruchomości są możliwe za zgodą właściciela.

Cele właściciela nieruchomości nie są jednolite. Zależą od indywidualnych preferencji klienta. Wśród nich wyróżnić należy (https://www.governica.com):

- cele finansowe,

- cele utylitarne,

- cele społeczno-gospodarcze.

Pośrednik nieruchomości, spełniając cele finansowe, dąży do osiągnięcia preferowanych przez właściciela dochodów z nieruchomości. W tym przypadku właściciel nie korzysta $\mathrm{z}$ nieruchomości lub korzysta $\mathrm{w}$ minimalnym zakresie. Biorąc pod uwagę cele utylitarne, pośrednik nieruchomości musi spełnić wymogi określonej nieruchomości użytkowej. Natomiast cele społeczne wynikają z preferencji właściciela publicznego (Bazan-Bulanda, Bartkowiak 2003, s. 24).

Istnieją profesjonalne organizacje zrzeszające pośredników i zarządców nieruchomości kierujące się kodeksem etyki zawodowej w dyscyplinie nieruchomości. Najbardziej znane federacje nieruchomości w Polsce to Krajowa Izba Gospodarki Nieruchomości oraz Polska Federacja Rynku Nieruchomości. Wyżej wymienione organizacje nieustannie monitorują szeroki zakres obowiązków i odpowiedzialności, które spoczywają na zawodzie pośrednika i zarządcy nieruchomościami (Rymarzak 2009, s. 64). W dalszym ciągu wymagają od swoich członków ciągłej aktualizacji wiedzy i profesjonalnych usług w celu zapewnienia usługobiorcy jak najwyższej ochrony jakości oraz poprawności wykonywanych zleceń (KIGN b.r., §1).

Każdy pośrednik analizuje sytuację rynkową prowadzącą do prawidłowej obsługi klientów. Nie podejmuje zadań, które wykraczają poza zakres jego wiedzy i doświadczenie zawodowe, jednak zawsze stara się pomóc klientom w uzyskaniu współpracy ze specjalistami w danej dziedzinie (Foryś (red.) 2006, s. 42). Przykładem owego działania jest współpraca pośrednika nieruchomości z bankami udzielającymi kredytów hipotecznych. W Polsce banki uniwersalne nie są bowiem wyznaczone do finansowania operacji na rynku nieruchomości. Tego typu działania mogą podejmować jedynie banki hipoteczne (Sitek 2010, s. 8).

W relacji z klientami pośrednik nie może dyskryminować osób zarówno ze względu na wyznanie, rasę czy pochodzenie. Musi dokładnie poinformować klien- 
ta o zakresie wykonywanej usługi, tym samym biorąc pod uwage poszanowanie praw wszystkich zainteresowanych stron (Śleszyńska 2008, s. 6-8).

Pośrednik nieruchomości powinien udzielać klientowi jasnych informacji na temat oferty, jak również informacje przekazywane przez klientów mogą zostać obarczone tajemnicą zawodową dla bezpieczeństwa przeprowadzanej transakcji (Matusiak 2006, s. 254).

\section{Charakterystyka biura Kubacki Nieruchomości}

Biuro Kubacki Nieruchomości jest szybko rozwijającą się firmą. Posiada licencję zawodową w zakresie pośrednictwa w obrocie nieruchomościami nr 1078 oraz zarządzania nieruchomościami nr 2178, jak również ubezpieczenie od odpowiedzialności cywilnej.

Mimo młodego stażu firma posiada kilkuletnie doświadczenie na rynku nieruchomości. Zdobyta wiedza, doświadczenie i profesjonalne podejście do każdego klienta stanowi podstawę dotychczasowych sukcesów, o czym świadczy grono zadowolonych klientów i duża liczba przeprowadzonych transakcji.

Pracownicy stale podnoszą swoje kwalifikacje, uczestnicząc w szkoleniach i zajęciach prowadzonych przez Krajowa Izbę Gospodarki Nieruchomościami.

Działalność biura nieruchomości oparta jest na świadczeniu usług w zakresie pośrednictwa w obrocie nieruchomościami mieszkaniowymi i komercyjnymi. Ponadto zakres działań obejmuje wynajem i sprzedaż nieruchomości.

Kubacki Nieruchomości gwarantuje wysokie standardy obsługi oraz doskonałą znajomość rynku nieruchomości. Warto nadmienić, że pośrednik jest z klientem podczas całego procesu trwania transakcji - od wyszukania i przedstawienia odpowiedniej nieruchomości po przekazanie nieruchomości i odbiór kluczy do własnego i wymarzonego lokum.

Działanie biura nieruchomości Kubacki Nieruchomości oparte jest na kilku krokach, takich jak:

- analiza rynku nieruchomości,

- analiza dokumentacji nieruchomości,

- ustalenie stanu prawnego nieruchomości,

- ustalenie szczegółów sprzedaży nieruchomości,

- wizja lokalna,

- przygotowanie oferty,

- umieszczenie oferty na stronie internetowej,

- sfinalizowanie oferty.

Kubacki Nieruchomości, analizując rynek, tworzy realną, szacunkową ofertę, za jaką można sprzedać powierzoną nieruchomość. W tym celu rzetelnie i bardzo skrupulatnie zbiera się wszystkie niezbędne informacje dotyczące nieruchomości, szczegółowo analizuje księgę wieczystą oraz mapy i wszystkie możliwe dokumenty przedstawione przez klientów. Następnie ustala się stan prawny oraz wszystkie szczegóły sprzedaży nieruchomości. W czasie wizji lokalnej na nieruchomości wykonuje się sesję fotograficzną oraz niezbędne pomiary w celu ustalenia dokład- 
nej powierzchni. Kolejnym krokiem w pracy jest umieszczenie oferty na stronie internetowej oraz na wiodących portalach nieruchomości.

Warto nadmienić, że biuro Kubacki Nieruchomości stara się reklamować poprzez szeroko pojęte działania marketingowe, takie jak: banery reklamowe, filmy ze wskazaniem nieruchomości z dronu, rozsyłanie ofert do firm. Wyżej wymienione akcje prowadzą klientów do jak najszybszej sprzedaży bądź dzierżawy swojej nieruchomości. Ostatnim elementem jest skompletowanie wszystkich dokumentów do przeniesienia praw własności nieruchomości.

\section{Wyniki badań ankietowych}

Grupę badawczą ankiety tworzyło 50 mieszkańców Częstochowy. Badanie zostało przeprowadzone w listopadzie 2017 roku. Wśród respondentów znajdowało się więcej mężczyzn, których było $58 \%$. W grupie ankietowanych najwięcej znalazło się osób pomiędzy 26. a 38. rokiem życia - 42\% badanych. Respondenci w przedziale wiekowym 18-25 lat to $16 \%$ badanych. Ankietowani w wieku $39-50$ lat stanowili $9 \%$ badanych. Najmniej liczną grupą okazali się respondenci powyżej 50. roku życia.

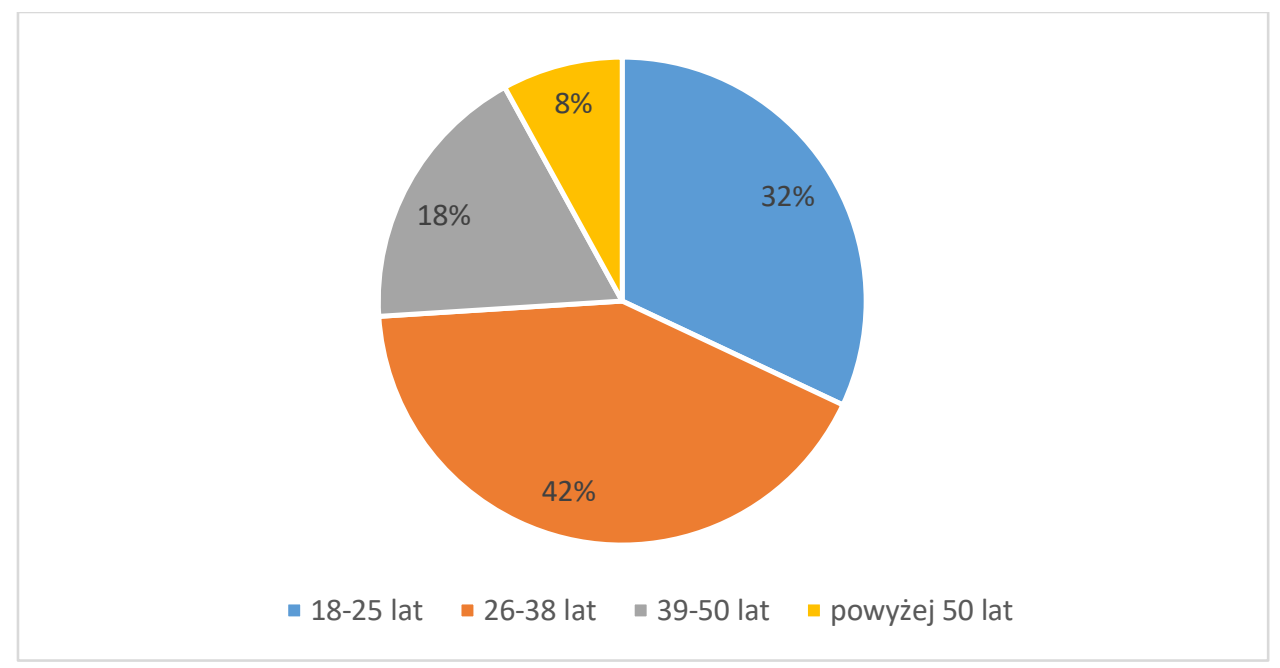

\section{Rysunek 1. Struktura wiekowa badanych}

Źródło: Opracowanie na podstawie badań własnych

Wśród respondentów dominuje wyższe wykształcenie - 66\% ankietowanych. $\mathrm{Na}$ drugim miejscu znajdują się częstochowianie o wykształceniu zawodowym $24 \%$. Na samym końcu - z wynikiem $2 \%$ - znajdują się respondenci o wykształceniu podstawowym. 


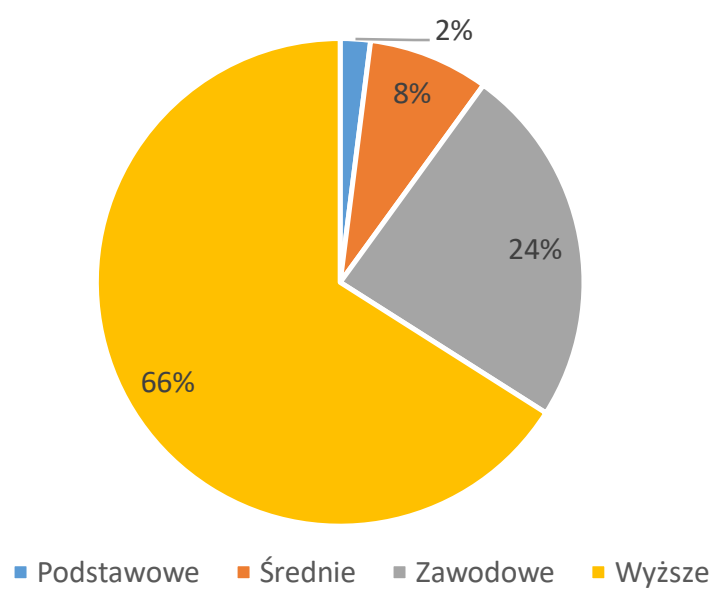

\section{Rysunek 2. Wyksztalcenie respondentów}

Źródło: Opracowanie na podstawie badań własnych

Największa liczba respondentów posiada miesięczne zarobki o wysokości powyżej 2500 zł. Na drugim miejscu znajdują się mieszkańcy o zarobkach 1801-2500 zł. Zatem dostrzec można, iż ponad połowa respondentów zarabia więcej niż $1800 \mathrm{zł}$ miesięcznie. W przedziale zarobków 1301-1800 zł jest bowiem jedynie 18\% respondentów.

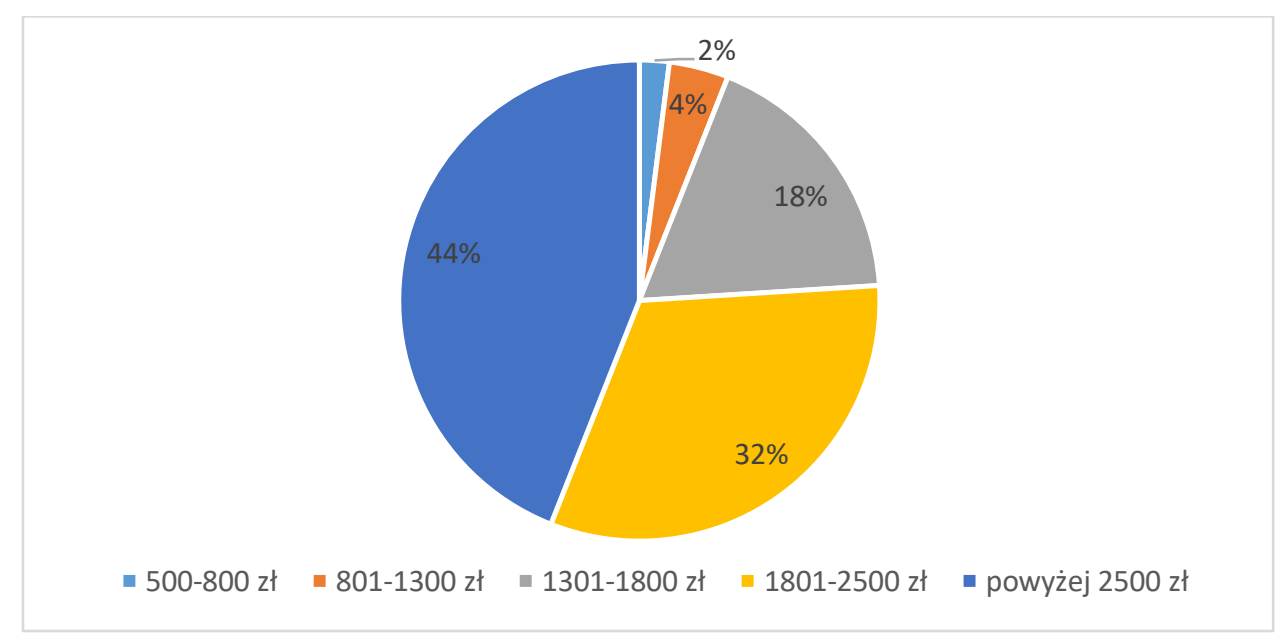

\section{Rysunek 3. Zarobki respondentów}

Źródło: Opracowanie na podstawie badań własnych

Preferencje mieszkaniowe często związane są z liczbą osób w gospodarstwie domowym. W ostatnim pytaniu metryczkowym respondenci zostali poproszeni o określenie liczby osób w gospodarstwie domowym. W związku z tym $42 \%$ osób 
przyznało, iż ich rodzina to 3-4 osoby. Natomiast 38\% badanych tworzy gospodarstwo 1-2-osobowe. Warto nadmienić, iż wraz ze wzrostem liczby osób w gospodarstwie domowym ilość wskazujących respondentów ulegała zmniejszeniu.

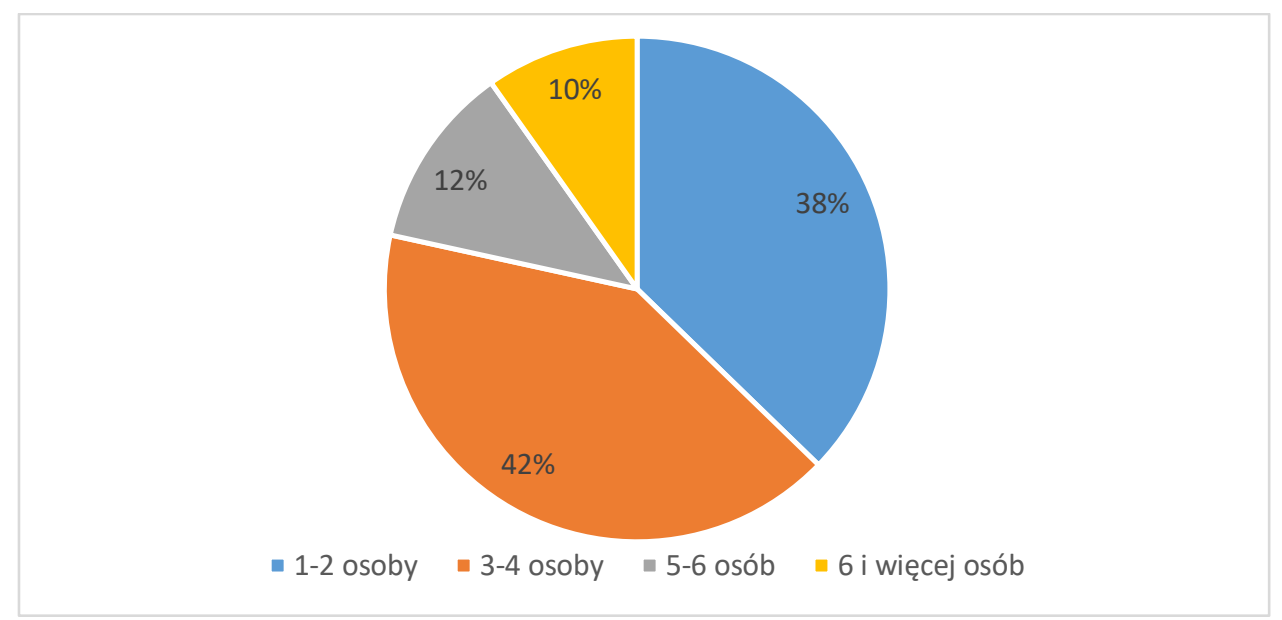

\section{Rysunek 4. Liczba osób w gospodarstwie domowym}

Źródło: Opracowanie na podstawie badań własnych

Na samym początku ankietowani zostali poproszeni o wskazanie rodzaju nieruchomości budzącej największe zainteresowanie. Według 34\% ankietowanych rodzajem nieruchomości wzbudzającej największe zainteresowanie potencjalnych klientów okazują się mieszkania. Na drugim miejscu znajdują się domy jednorodzinne - odpowiedź ta uzyskała $25 \%$ wskazań. Ankietowani wykazali również zainteresowanie nieruchomościami takimi jak: działki (21\%) oraz lokale użytkowe $(16 \%)$.

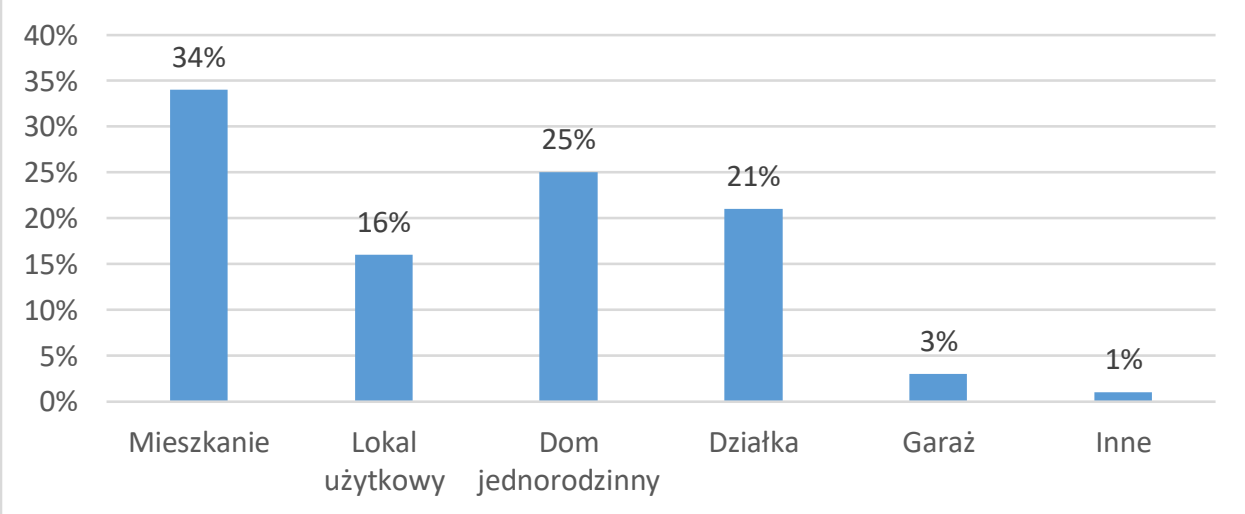

Rysunek 5. Nieruchomości wzbudzające największe zainteresowanie

Źródło: Opracowanie na podstawie badań własnych 
Wśród transakcji zawieranych najczęściej za pośrednictwem biura nieruchomości znajdują się kupno oraz sprzedaż nieruchomości. Odpowiedzi te osiągnęły przewagę 75\%. Respondenci są zainteresowani również usługą wynajmu nieruchomości przy pomocy biura. Odpowiedzi tej udzieliło $20 \%$ ankietowanych (Rysunek 6).

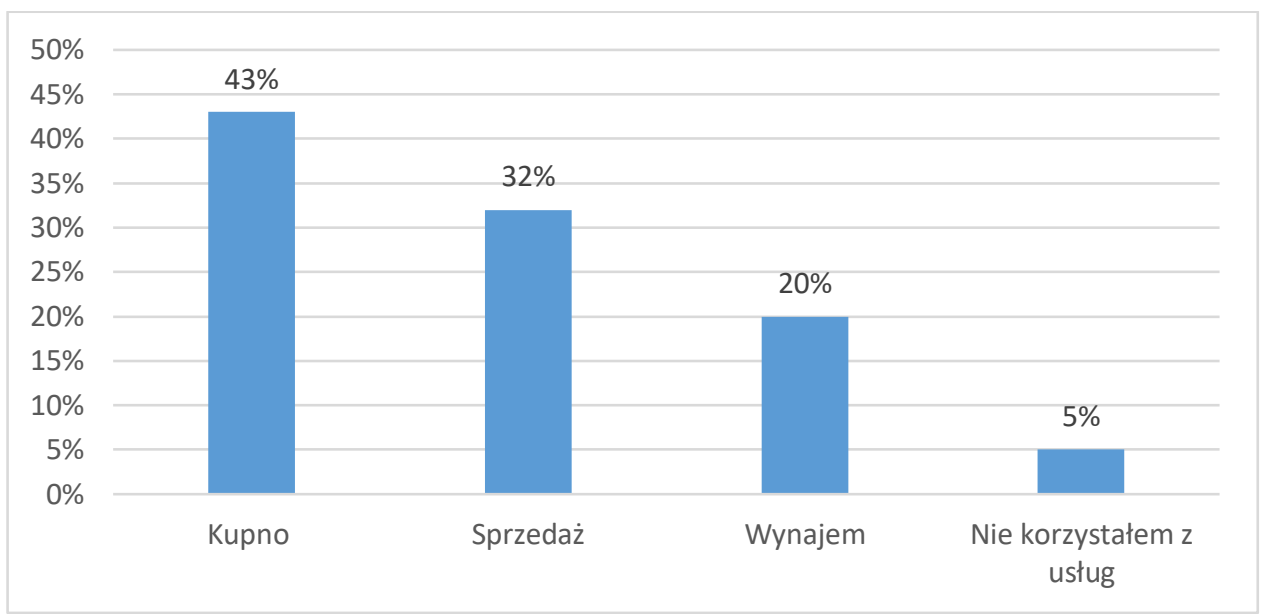

Rysunek 6. Rodzaje transakcji z biurem nieruchomości budzące zainteresowanie

Źródło: Opracowanie na podstawie badań własnych

W kolejnym pytaniu ankietowani zostali poproszeni o wskazanie dotychczasowego sposobu poszukiwania lokalu. Widoczną przewagę osiągnęly odpowiedzi: indywidualne poszukiwania (38\%) oraz pomoc znajomych (34\%). Niestety jedynie $14 \%$ respondentów skorzystało do tej pory z pomocy biura nieruchomości. Identyczną wartość osiągnęła pomoc ze strony rodziny (Rysunek 7).

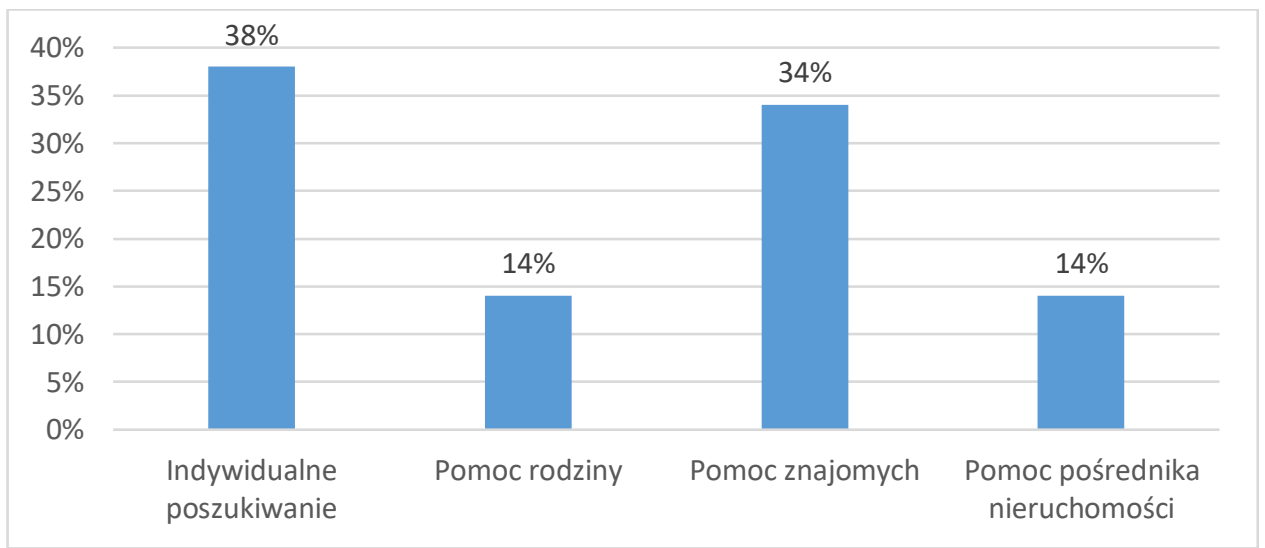

Rysunek 7. Sposoby dotychezasowych poszukiwań lokalu

Źródło: Opracowanie na podstawie badań własnych 
Informacje na temat wybranego biura nieruchomości najczęściej pozyskiwane są ze strony internetowej firmy (27\%). Skuteczna okazuje się również reklama za pośrednictwem radia (20\%) oraz polecenie bliskiej osoby (18\%) (Rysunek 8$)$.

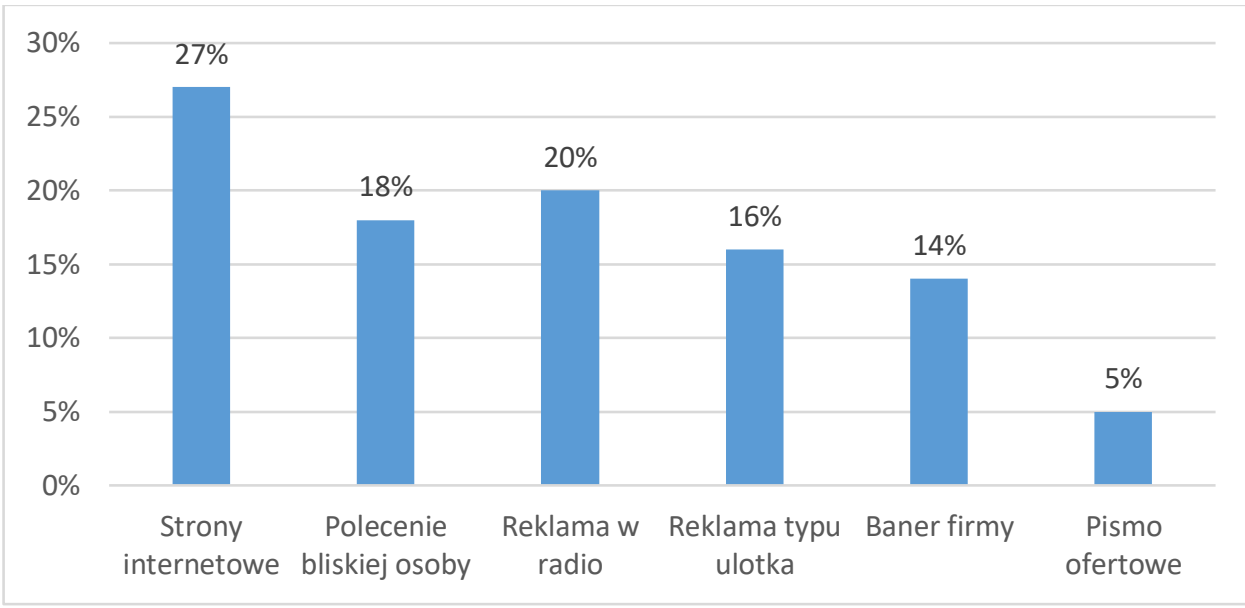

Rysunek 8. Źródła informacji pozwalające dotrzeć do danego biura nieruchomości

Źródło: Opracowanie na podstawie badań własnych

Ponad połowa respondentów wykazuje zadowolenie z usług biura nieruchomości. Pozytywną opinię w tym temacie wyraziło $90 \%$ ankietowanych. Niezadowolenie przejawiło $4 \%$ respondentów. Natomiast $6 \%$ badanych nie miało zdania w powyższym temacie (Rysunek 9 ).

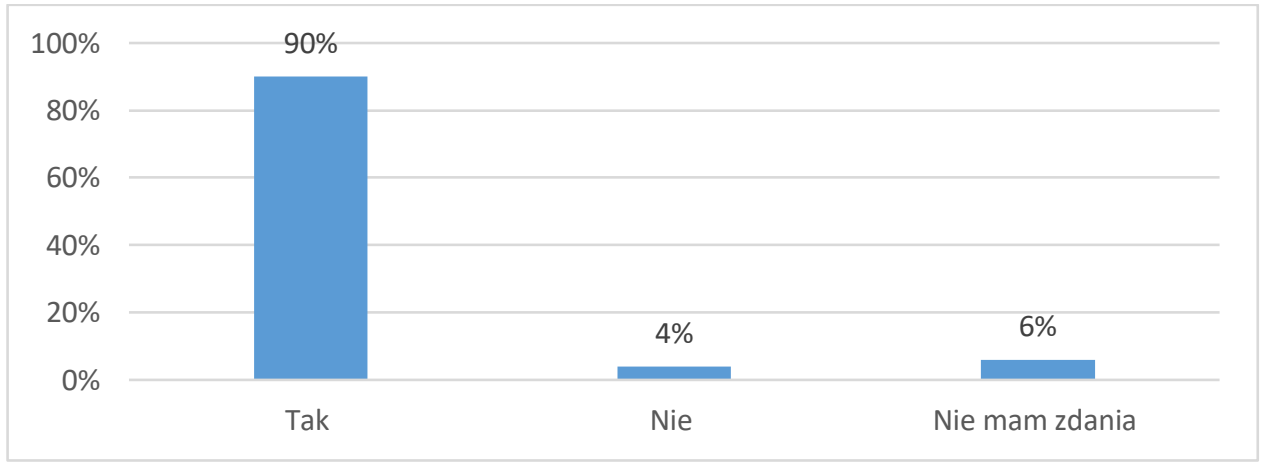

Rysunek 9. Zadowolenie z dotychczasowej pomocy biura nieruchomości

Źródło: Opracowanie na podstawie badań własnych

W kolejnym pytaniu respondenci zostali poproszeni o wskazanie cech dobrego biura nieruchomości. Wśród ankietowanych najbardziej docenione są cechy takie jak doświadczenie (37\%) oraz rzetelność (30\%) (Rysunek 10). 


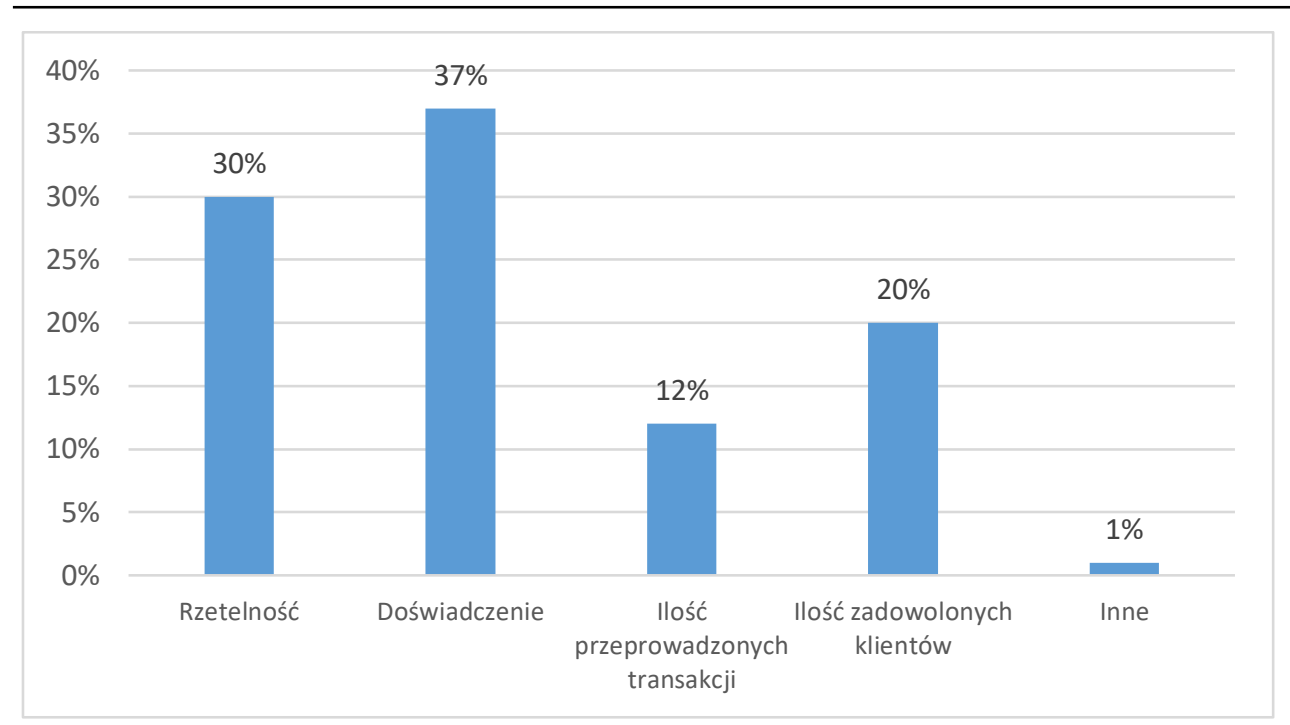

\section{Rysunek 10. Cechy dobrego biura nieruchomości}

Źródło: Opracowanie na podstawie badań własnych

W kolejnym pytaniu respondenci zostali poproszeni o wyrażenie zdania na temat komfortu korzystania z biura nieruchomości. Aż 90\% badanych uważa, że pomoc biura nieruchomości jest nieoceniona, znacznie bardziej komfortowa podczas poszukiwania. Jedynie $4 \%$ badanych jest zdania, że usługi biura nie dają komfortu jego klientowi (Rysunek 11).

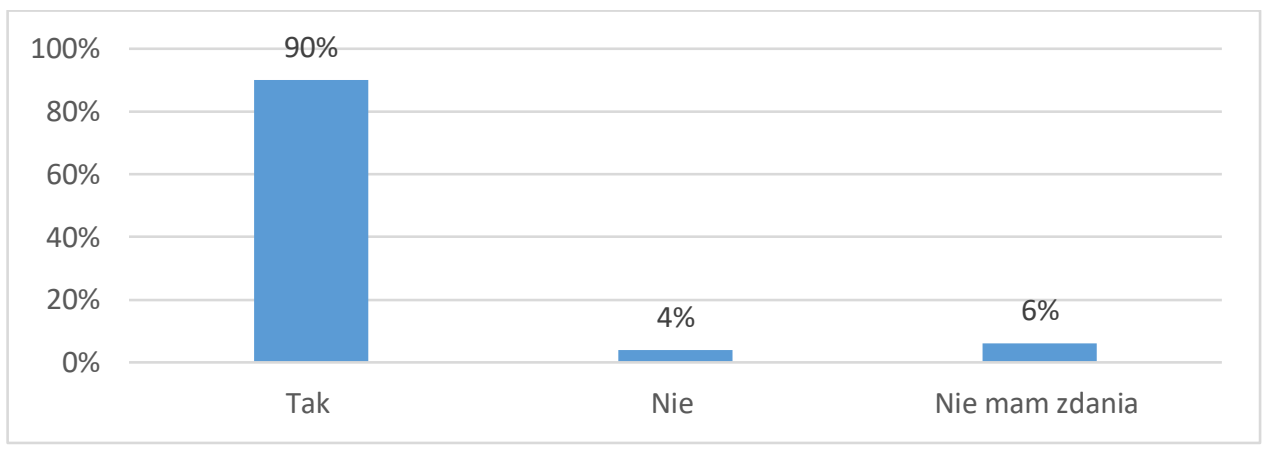

\section{Rysunek 11. Komfort korzystania z biura nieruchomości}

Źródło: Opracowanie na podstawie badań własnych

Wykwalifikowany pośrednik nieruchomości poprzez swe doświadczenie i znajomość rynku jest pomocny podczas poszukiwania nieruchomości. Czy zatem korzystanie z biura nieruchomości okazuje się bardziej bezpieczne niż poszukiwanie na własną rękę? Otóż $88 \%$ badanych uważa, że udanie się do pośrednika nieruchomości gwarantuje bezpieczeństwo. Odmiennego zdania jest natomiast $8 \%$ respondentów (Rysunek 12). 


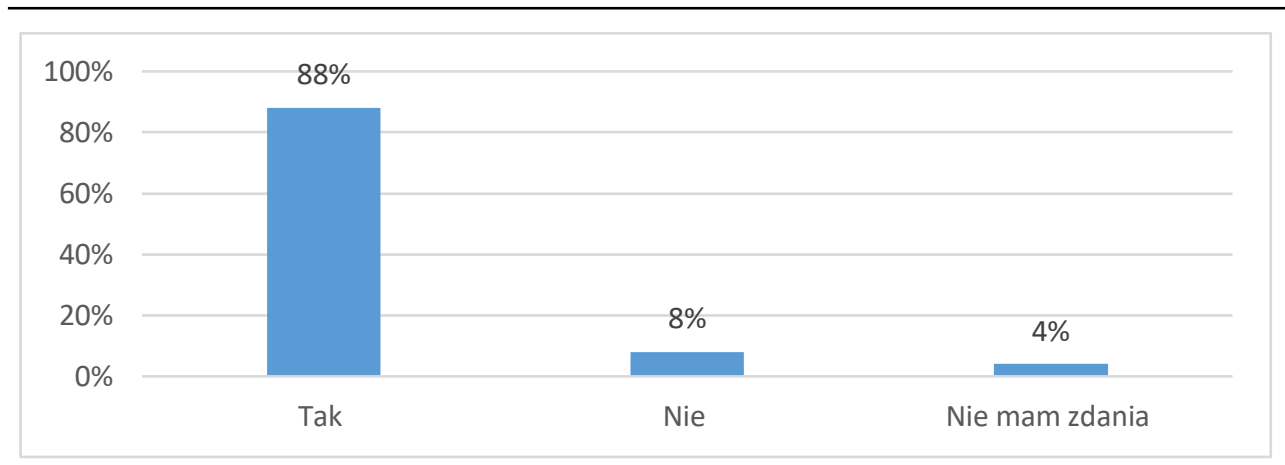

Rysunek 12. Bezpieczeństwo korzystania z biura nieruchomości

Źródło: Opracowanie na podstawie badań własnych

Według ankietowanych wyższe wykształcenie kierunkowe oraz licencja zawodowa są konieczne podczas wykonywania zawodu agenta nieruchomości (Rysunek 13). Ponad połowa ankietowanych (88\%) uważa, że nie każdy może zostać dobrym agentem nieruchomości, o wyborze odpowiedniego agenta świadczy jego wykształcenie. Jedynie $10 \%$ ankietowanych uważa inaczej - według nich skuteczność agenta nieruchomości nie musi iść w parze z posiadanymi kwalifikacjami zawodowymi.

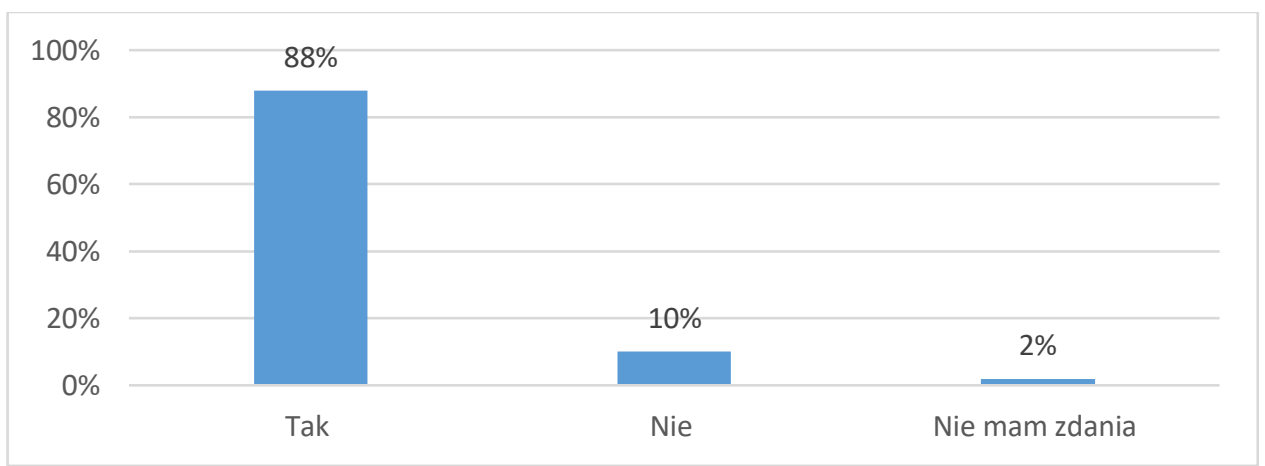

Rysunek 13. Konieczność posiadania przez dobrego agenta nieruchomości wyższego wykształcenia kierunkowego i licencji zawodowej

Źródło: Opracowanie na podstawie badań własnych

Mimo szeregu cech opisujących biuro nieruchomości ankietowani cenią przede wszystkim minimalną prowizję pośrednika nieruchomości $-24 \%$ wskazań. $\mathrm{Na}$ drugim miejscu wśród oczekiwań w odniesieniu do biura nieruchomości znajduje się znalezienie idealnej oferty $-22 \%$ głosów. Jak widać, odpowiedzi te są bezpośrednio związane z ofertą kierowaną przez biuro nieruchomości (Rysunek 14). 


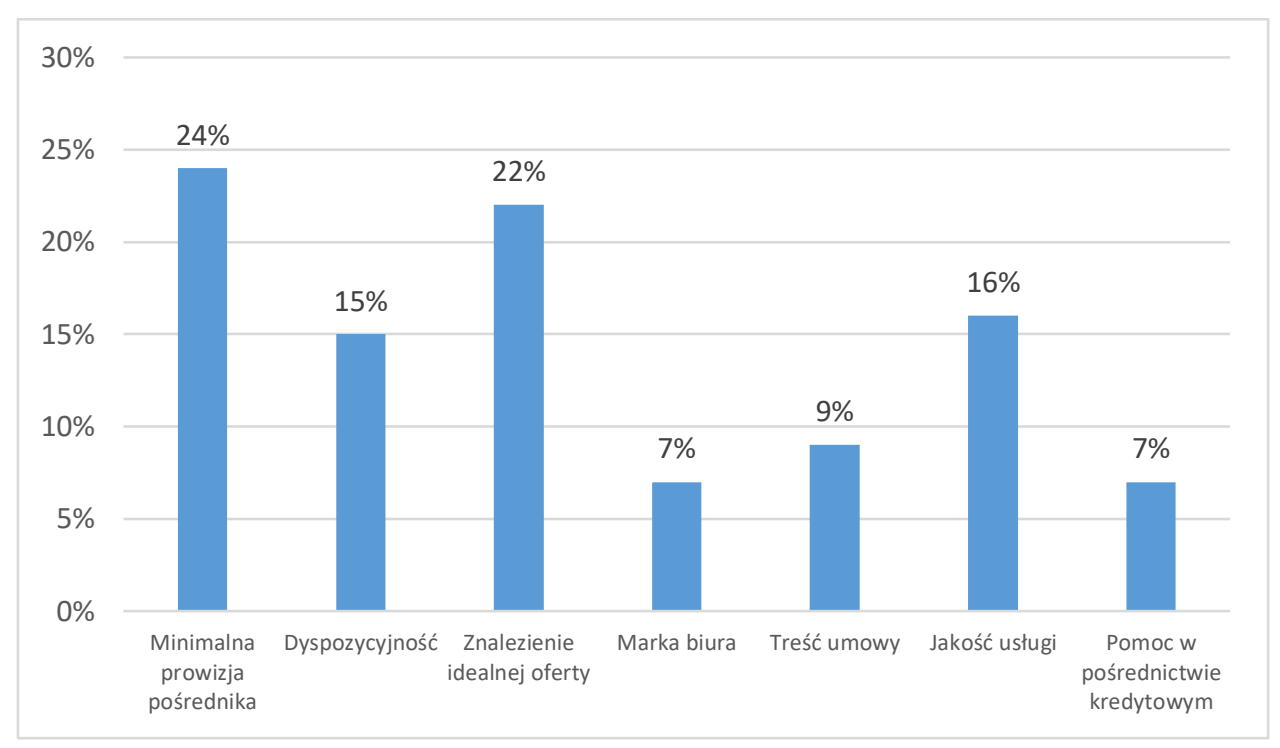

\section{Rysunek 14. Oczekiwania wobec biura nieruchomości}

Źródło: Opracowanie na podstawie badań własnych

Ankietowani rzadziej patrzą na aspekty niefinansowe, takie jak: dyspozycyjność czy jakość obsługi. Odpowiedzi te osiągnęły ok. 16\% wskazań. Ponadto mała liczba osób oczekuje od biura nieruchomości odpowiedniego poziomu marki czy też pomocy w pośrednictwie kredytowym.

\section{Podsumowanie}

Zawód pośrednika nieruchomościami jest $\mathrm{w}$ dalszym ciągu bardzo ważnym zawodem wysokiego ryzyka, ponieważ na osoby wykonujące go czeka duża konkurencja i sporo trudnych do realizacji ofert nieruchomości.

W obecnych czasach od agenta nieruchomości oczekuje się bardzo wiele. Praca agenta to bardzo trudny zawód. Wymaga połączenia wiedzy i umiejętności z wielu dziedzin, takich jak sprzedaż, budowanie relacji, negocjacje itp., i oczywiście wiedzy o rynku nieruchomości, który potrafi się bardzo różnić nie tylko pomiędzy jednym a drugim miastem, ale nawet pomiędzy sąsiadującymi ze sobą dzielnicami.

Pośrednicy w swoim zawodzie dobrze znają tendencje rynkowe oraz ustawę o gospodarce nieruchomościami, tak aby rzetelnie doradzać zainteresowanym ich usługami klientom. Aby nadążyć za obowiązującymi trendami, stale muszą podnosić swoje kwalifikacje oraz pogłębiać wiedzę. Wynika to $\mathrm{z}$ faktu, iż rynek nieruchomości jest bardzo płynny na tle pojawiających się różnorakich ofert. Przeprowadzona ankieta pokazuje, jak ważne jest korzystanie z usług biura nieruchomości. Zadowalający jest fakt, iż przy sprzedaży nieruchomości poszukujący korzystają z pomocy pośrednika nieruchomości. Informacje na temat biura najczęściej wyszu- 
kiwane zostają poprzez portale internetowe, dużym zainteresowaniem cieszy się również polecenie bliskich bądź znajomych.

Działanie pośrednika nieruchomości gwarantuje duże bezpieczeństwo transakcji oraz fachową obsługę. Wśród cech pożądanych wśród agentów nieruchomości respondenci cenią najbardziej: rzetelność, doświadczenie oraz opinię zadowolonych klientów. Ponadto ankietowani cenią sobie wykształcenie pośrednika. Mimo nowych deregulacji prawnych klienci zwracają uwagę na posiadanie przez pośrednika odpowiednich uprawnień, takich jak licencja pośrednika bądź zarządcy nieruchomości. Fakt ten daje im większe bezpieczeństwo w zawieraniu transakcji. Najczęściej zawierane transakcje $\mathrm{w}$ biurach nieruchomości to transakcje kupnasprzedaży prawa własności. Nieliczna grupa osób interesuje się również wynajmem. Klienci przede wszystkim stawiają na jak najmniejszą prowizję ze sprzedaży dla pośrednika. W dalszej kolejności stawiają na znalezienie idealnej oferty.

W dzisiejszych czasach, kiedy wszyscy są zabiegani i zajęci swoimi obowiązkami, nabywcom domów lub mieszkań z pomocą w ich poszukiwaniach przychodzi pośrednik nieruchomości. Pośrednik słusznie oceni wartość nieruchomości, fachowo i profesjonalnie zaprezentuje nieruchomość potencjalnym kupcom, dokładnie przedstawi wady i zalety danego lokum.

\section{Literatura}

1. Bazan-Bulanda A., Bartkowiak P. (red.) (2003), Zarządzanie małym i średnim przedsiębiorstwem $w$ Polsce $i$ w krajach Unii Europejskiej. Teoria i praktyka, t. 2, Wydawnictwo Wydziału Zarządzania Politechniki Częstochowskiej, Częstochowa.

2. Bończak-Kucharczyk E. (2013), Ustawa o gospodarce nieruchomościami. Komentarz, Wolters Kluwer, Warszawa.

3. Bończak-Kucharczyk E. (2014), Zarządzanie nieruchomościami mieszkalnymi. Aspekty prawne i organizacyjne, Wolters Kluwer, Warszawa.

4. Bryx M. (2008), Rynek nieruchomości. System i funkcjonowanie, Poltext, Warszawa.

5. Brzeski W. (red.) (2003), Vademecum zarządcy nieruchomości, Krakowski Instytut Nieruchomości, Kraków.

6. Brzeziński Z. (2008), Pośrednik na rynku nieruchomości, Poltext, Warszawa.

7. Cabała P. (red.) (2018), Zarządzanie portfelem projektów w organizacji. Koncepcje i kierunki badań, Mfiles, Kraków.

8. Foryś I. (red.) (2006), Zarządzanie nieruchomościami komercyjnymi, Poltext, Warszawa.

9. http://www.governica.com (dostęp: 30.12.2017).

10. http://www.kubackinieruchomosci.pl (dostęp: 28.12.2017).

11. KIGN (b.r.), http://www.kign.pl/o-izbie/wewnetrzne-regulacje-izby/127/kodeks-etyki-zarzadcow -nieruchomosci-oraz-posrednikow-w-obrocie-nieruchomosciami (dostęp: 10.12.2017).

12. Matusiak J. (2006), Peryferyjny kapitalizm zależny, b.w., b.m.

13. Obwieszczenie Marszałka Sejmu Rzeczypospolitej Polskiej z dnia 14 grudnia 2017 r. w sprawie ogłoszenia jednolitego tekstu ustawy o gospodarce nieruchomościami (Dz.U. 2018 poz. 121).

14. Rymarzak M. (2009), Zarządzanie nieruchomościami przedsiębiorstw w Polsce, CeDeWu, Warszawa.

15. Sitek M. (2010), Bankowość hipoteczna i rynek nieruchomości, Key Text, Warszawa.

16. Stabryła A. (red.) (2010), Zarządzanie w kryzysie, Mfiles, Kraków. 
17. Śleszyńska E. (2008), Podstawy prawne działalności zawodowej zarządcy nieruchomości w Polsce $i$ w Unii Europejskiej, Minigo, Warszawa.

18. Tomski P., Sitek M. (red.) (2011), Współdziałanie gospodarcze podmiotów na rynku nieruchomości, Sekcja Wydawnictw Wydziału Zarządzania Politechniki Częstochowskiej, Częstochowa.

19. Ustawa z dnia 13 czerwca 2013 r. o zmianie ustaw regulujących wykonywanie niektórych zawodów (Dz.U. 2013 poz. 829).

20. Ustawa z dnia 21 sierpnia 1997 r. o gospodarce nieruchomościami (Dz.U. 1997 nr 115 poz. $741, \mathrm{z}$ późn. zm.).

21. Wolniakowska K. (red.) (2013), Zarządzanie podmiotami gospodarczymi w turbulentnym otoczeniu. Aspekty teoretyczne i praktyczne, Sekcja Wydawnictw Wydziału Zarządzania Politechniki Częstochowskiej, Częstochowa.

\title{
EVALUATION OF THE REAL ESTATE PROCESSOR'S EXHIBITION A CASE STUDY OF CZĘSTOCHOWA REAL ESTATE OFFICE
}

\begin{abstract}
The main purpose of this article is to show the specifics of managing a real estate agency. The study is divided into two parts: theoretical and empirical. The theoretical part describes the profession of a real estate broker in real estate management, its duties, and key objectives. Additionally, the article presents one of the Częstochowa real estate agencies. The empirical part is a questionnaire survey carried out among the clients of the said agency. The collected data made it possible to assess the importance of the profession of a real estate broker and the frequency with which its services were used by a real estate agency in its business operations.
\end{abstract}

Keywords: real estate, real estate broker, real estate office management, property owner 